\title{
Weaknesses of Financial Market Regulation
}

\author{
Christian A. Conrad \\ Correspondence: Christian A. Conrad, University of Applied Science HTW, Waldhausweg 14, 66123 Saarbrücken, \\ Germany.
}

Received: December 15, 2017

Accepted: January 2, 2018 Available online: January 4, 2018

doi:10.11114/aef.v5i2.2914

URL: https://doi.org/10.11114/aef.v5i2.2914

\begin{abstract}
In this paper we examine the extent newer developments affect the economic processes of the market and put financial markets at risk. We also analyze if the financial market regulations are sufficient to limit the systemic risk they cause. The biggest Shortcoming of the recent reforms to the stabilization of the financial system, such as Basel III and the American Dodd Frank Act, is that they increase the capital requirements rather than the causes of the increased risk. It would generally be better to forbid risky and complex financial products than to further increase regulation complexity and the capital requirements as in Basel III and the American Dodd Frank Act.
\end{abstract}

Keywords: derivatives, financial market regulation, ratings, value at risk, financial crisis, Basel III, Dodd Frank Act

JEL classification: F55, G13, Q11, Q31

\section{Introduction}

After the financial crisis several studies analyzed the risks management practices and came to the conclusion that the investors have underestimated the risks due to products complexity and over-reliance on quantitative analysis (studies by the Financial Stability Forum, the Working Group on Risk Assessment and Capital, the Senior Supervisors Group, the Basel Committee on Bank Supervisions, the International Institute of Finance and the International Monetary Financial Committee) (Voinea \& Anton, 2009).

New financial instruments such as derivatives showed their risk potential in the financial crisis. There were also new market participants, whose market influence has grown. By using a qualitative research approach we examine in this paper the extent to which these two developments affect the economic processes of the market and put financial markets at risk. We also analyze the extent to which the new financial market regulations Basel III and the American Dodd Frank Act are sufficient to limit the systemic risk they cause.

\section{Risk and Non-Transparency in Derivatives}

One central problem in the financial crisis were the bilateral over-the-counter derivatives (OTCs), which are not traded on the stock exchange and therefore not registered. The supervisory authorities still do not know the exact amount and distribution of the derivatives, which means they cannot know the systemic risk (e.g. the CDS to Greece in the European debt crisis) and cannot intervene. In the financial crisis, the counterparty risks were not properly priced, for example through a reasonable capital securitization. The default of a counterparty or credit could lead to a system risk as a result of contagion, as in the case of Lehman.

Basel III and the Dodd Frank Act provide a framework for trading via central clearing houses (stock exchanges) as well as standards for a collateral deposit of the CDS seller and a capital backing which the CDS buyer must take to hedge the counterparty risk. The equity requirements of derivatives is determined by comprehensive models; the rating-related bond equivalence approach and the internal Advanced CVA (Credit Value Adjustment) approach, which is based on market data, specifically spreads, have been developed for this purpose (Hofman, 2011; Deutsche Bundesbank, 2011; Peirce \& Soliman, 2016; Giancarlo, 2016). For the remaining OTC derivatives, higher equity requirements apply to counterparty risk, which makes them unattractive to banks. The volume of OTC derivatives is already decreasing (Gaumert, Götz \& Ortgies, 2011; Conrad, 2013). However, the collateral provided and the equity capital for the counterparty risk are insufficient to cover the systemic risk of derivatives. The financial crisis has shown very clearly how fast market data can change. If the spreads of the CVA and ratings of the bond equivalence approach change, banks must collateralize the difference. 


\section{Market Influences by Derivatives}

\subsection{Futures}

Krugman considers speculation to be a zero-sum game. Every futures long contract is accompanied by a short contract, which is why he does not see any influence on prices. "Buying a futures contract for oil does not reduce the quantity of oil available for consumption; there's no such thing as "virtual hoarding"." (Krugman, 2008, June 21). One must point out however, that the supply and demand might not be influenced on the spot market, but they are on the futures market. Of course a futures contract can only be concluded on the futures market if there is a short position corresponding to the long position, but excess demand will only increase prices until a market participant considers the offset lucrative. If everything else stays the same, an additional demand for commodities increases prices on futures markets. Even if futures prices do not influence spot prices with a supply scarcity resulting from increased stock holding, it is still possible for expectations to have an influence. Lagi et al. (2011) have shown this: “... we interviewed participants in the spot market who state unequivocally that they base current prices on the futures market. The use of futures prices as a reference enables speculative bubbles on the futures market to influence actual food prices."

Krugman is correct that speculation is in principle a zero-sum game. What one actor wins, another must lose. In the case of commodity speculation, the speculators can fulfill an important function by buying forward the commodities from downstream users and thus reducing the risk of price changes. In such a case they fill the purpose of insurance, which is also a central argument of those in favor of unimpeded speculation (Pies, Prehn, Glauben \& Will, 2013).

With the substitute insurance argument however, we must remember that a producer can be facing up to 4 speculators and thus speculation goes far beyond simple insurance. The speculators may buy and sell amongst one another (Domanski \& Heath, 2007), which can lead to an increase of futures prices with excess demand. The index funds invested almost exclusively long until the peak of 2008, which created a great deal of excess demand (Stoll \& Whaley, 2009).

Does speculation have an effect on spot prices that would increase living costs with unethical effects, especially for poor countries? The fact is that financialization has caused new market participants to join commodities and agricultural markets with distinct economic motivations. Because the investors are interested in diversifying their portfolios, massive long positions built up until the financial crisis. Many billions of dollars thus came into the markets as additional demand. Since the investors did not want the commodities delivered, the additional demand had a direct influence only on futures markets, not on spot markets. This caused an increase in the secure stock profits that, as long as they were greater than the cost of storage, would lead sooner or later to a scarcity in supply and thus to increased spot market prices. We can therefore assume an influence of futures prices on spot prices if the excess demand on the futures market is high and stays high over a longer time period. If commodity and agriculture producers think futures prices are at a historic high they will sell their production forward, which removes the supply from the future spot market. Increasing prices for end and intermediate goods involving commodities and agriculture products are also possible if the downstream producers secure their positions on futures markets. Thus we come to the conclusion that speculation influences spot prices of commodities and food prices if it creates a significant excess demand over a significant time period. In this case speculation might be seen as unethical, why regulation is needed (Conrad, 2014).

\subsection{Credit Default Swaps}

The impacts of credit default swaps are still contentious. There are the so-called Naked CDS as derivative loan loss insurance without underlying loans. There are those who see a positive effect even in speculative credit default swaps because of the higher liquidity in the market. There are also market participants who believe that the interest rates of the Greek government bonds would be higher if the investors could not insure themselves against a CDS default. However, the Greek Government complained that the betting of hedge funds on Greek bankruptcy over the purchase of CDS would have led to higher margins in Greek government bonds in the European debt crisis. Who is right?

If many hedge funds are speculating against European government bonds, for example, they buy the corresponding CDS as a credit default insurance. This leads to an increase in the CDS spreads, which is not only seen as a reflection of the bond yields but is also seen as a risk indicator by the market participants, thus directly and indirectly driving up the price of the bonds. George Soros also sees the CDS 'very critically'. In his opinion, there is the risk of a "bear raid", i.e. a profitable price influence, at CDS due to the asymmetric risk distribution between the buyer (limited risk of loss, value or premiums of the CDS) and the seller (high risk of loss in the event of bankruptcy). A purchase of CDS' increases the borrowing costs of the borrower and thereby improves its credit rating, which in turn increases the value of the CDS'. According to George Soros, this connection together with the shortselling of the shares caused the collapse of Lehman, AIG and Bear Stearns (Soros, 2009).

The risk of a "bear raid" originates from derivatives because their value is determined by real prices. Due to the theoretically unlimited leverage of derivatives, in small-volume markets it may be worthwhile to influence or 
manipulate the real price on the market in order to be successful with the derivatives position. This was the basis for the arrangements for Libor and gold fixing between major international banks. Even a collectively coordinated behavior for the manipulation of the courses can not be ruled out in smaller markets.

\section{Weaknesses of Risk Indicators and Pricing Methods}

\subsection{Ratings}

Uniform ratings are dangerous because all market players are subject to this assessment. If securities such as AAA-rated CDOs prove to be worthless in the financial crisis, asset bubbles can occur, followed by asset crashes. The financial innovations created a false sense of security with their complex mathematical models and AAA ratings. One of the main causes of the subprime crisis was that investors relied on the credit judgements of the rating agencies. The ratings were too good, which meant that the credits were understated with insufficient capital and that during the crisis the valuation adjustments put the creditors at risk.

The Dodd Frank Act decouples the acceptable amount of capital securitization from external ratings. In general, the regulatory and supervisory authorities should remove all references to (Dullien, 2012) external ratings and rating agencies from the regulations. In addition, the Dodd Frank Act subordinates the rating agencies to the SEC. The SEC will regularly monitor the ratings and methods of the agencies and impose fines in the event of infringements, which may include the revocation of licenses. In the financial crisis, rating agencies were not responsible for their valuations. According to the Dodd Frank Act, the rating agencies can be sued for damages by the investors in case of grossly negligent rating errors (US-Senate).

The German Council of Experts still sees a risk in wrong or matching external ratings. In the Liquidity Coverage Ratio (LCR) of Basel III, government bonds are equated with cash and, in principle, the government bonds are weighted lower in the net-stable funding ratio (NSFR). All OECD government bonds and loans are weighted at zero capital, which is what the EU Commission has assumed for the EU Member States (European Commission, 2012). As a result, government bonds are preferred by the supervisory regulations, which is why it is assumed that the banks will continue to invest disproportionately in government bonds.

While this preference is desirable for governments, it raises the systemic risk substantially, which does not make sense in view of the present state debt crisis. This preference for government bonds is currently being discussed and has also prompted the Advisory Council to point to the risk of lump risks associated with government bonds. He also proposed foregoing a risk weighting of the claims and advocated large credit limits on government bonds (especially those of one's own state) (Sachverständigenrat, 2011). In the case of bonuses based on equity returns, the zero risk weighting causes moral hazards and discriminates against other loans, such as companies (Schäfer, 2011). In general, risk weighting is an incentive to manipulate ratings.

\subsection{Value at Risk and Option Pricing Models}

The problem with a distorting basis of past values is that it results in other capital market approaches, such as the value at risk (VaR) (Taleb, 2001, 2007), a risk indicator for securities, mainly derivatives, which is based on the historical value changes (volatilities) or assumed distributions of future influencing factors (Conrad, 2010). VaR failed as risk indicator in the financial crisis (Stulz, 2009). VaR models assume that prices correspond to a normal distribution. The occurrence of the financial crisis was incompatible with the assumption of a normal distribution. There are such "fat tail" phenomenon every five to ten years (Crotty, 2009). Actually, the term "value at risk" promises too much and encourages a false sense of security, because the risk is the maximum possible loss and this is usually the capital employed. In order to circumvent the historical limitations of environmental conditions, Basel III prescribes fictitious stress scenarios for the VAR models (Deutsche Bundesbank, 2011). This is a significant improvement, but it should be a general understanding that the future remains unpredictable, and the rating is a very imprecise estimate (Stahl \& Conrad, 2000).

The best example of the non-calculability of the economy is the option price formulas (Black \& Schools formula). Robert Merton, Myron Scholes and Fischer Black received the Nobel Prize for Breaking Breakthroughs in War Warfare. Building on the volatilities of the past, they developed formulas for the price of buying or selling rights to values that can be exercised in the future (options). It is therefore apparently an instrument with which one can calculate the future, which is why they are also suitable for speculation. A hedge fund hired Robert Merton as a consultant. In 1998, this hedge fund, with the name Long Term Capital Management (LTCM), lost 90\% of the \$ 4 billion invested and threatened to trigger a chain reaction on the international financial markets.

This was not only about the loans taken by the LTCM, but also by the derivative positions drawn up by the LTCM as a counterparty, which had secured other financial market participants. It was not until the then Federal Reserve president Alan Greenspan personally intervened and created a several billion dollar rescue package, that the capital market crisis could be averted (Single \& Stahl, 2000). In 2006, the second Merton advisory hedge fund with the lofty name IFC Continuum closed. So the future could not be calculated. 
The weakness of the option price theories or risk indices such as value at risk, which are based on historical volatilities, is that they do not represent the future supply and demand ratios. For example, Porsche was able to buy the majority of VW stock by buying call options more favorably than on the stock market and increased its VW share secretly to $74 \%$. The option prices did not reflect the scarcity of VW shares, as they had been calculated on the basis of past price fluctuations. They were much too low. The demand overhang then led to a short squeeze.

\subsection{Is Risk Calculable?}

Just like the Classic-Neoclassic theory after the Great Depression in 1929, today's economic theory has explanation and justification problems. The statistical models neither foresaw the crisis nor are they now able to explain it. Moreover, the econometric models based on historical figures presumed a safety where there was none, which was in itself one reason for the crisis (Stulz, 2009).

Ratings are estimates of future developments based on past figures. Strictly speaking, the risk of default cannot be calculated because the possible environmental conditions and the probability of their occurrence are not known. Unlike the static experiment of throwing a coin, the basic conditions of random events change constantly. The financial crisis has once again shown how quickly ratings can turn out to be wrong or fall behind events. The risk models thus led to an increase in the systemic risk rather than to a reduction. Nassim Nicholas Taleb wrote about the delusions of control and reliability under which much of Wall Street and many other businesses function. He pointed at the dangers of trusting the "bell-curve" models used by many financial institutions to mitigate risks. He questions the reliance on past historical information and uses the example of the black swan, which nobody expected until its discovery in Australia or the example of the turkey who spends a thousand days being well fed before being killed on the thousand-and-first day (Taleb, 2001, 2007). Justin Fox also criticises the belief in models and especially the belief in efficient markets - a belief which was qualified by Robert Shiller as the "most remarkable error in the history of economic theory." (Fox, 2009; Malkiel, 2014).

We acknowledge that due to the countless and constantly changing environmental influences and the unpredictable factor of man, only trend forecasts for economic development can be made. This was already recognized by Hayek. There can be only so-called "pattern predictions" (Hayek, 2014).

Even after the financial crisis, the principle still applies that the worse the rating the more equity capital needs to be put aside in order to cover the default risk. Oddly, Basel III and the Dodd Frank Act massively increased the capital requirements for banks (Kern, 2010). The proposals of the Basel Committee on Banking Supervision (BCBS), as well as those of the Swiss and British expert groups, called for even higher capital requirements on investors (Sachverständigenrat, 2011). On the other hand, no one can predict how the ratings will change in a crisis and thus also how high the capital requirements will be in order to prevent the insolvency of a system-relevant institution. For example, according to the Basel II criteria, the Swiss UBS had a constant risk-weighted equity ratio of $10 \%$, while the unweighted equity ratio had already fallen to $2 \%$ (Sachverständigenrat, 2011).

Basel III tries to solve this problem by a $2.5 \%$ additional anticyclical capital buffer (Gaumert, Götz, \& Ortgies, 2011). This is a good approach but arbitrary and inconsistent. No one can guarantee that this buffer is sufficient. If credit or default risks are still weighted with ratings, any accuracy that does not correspond to reality is just made up. The financial crisis has shown that ratings are too uncertain as a future prognosis in order to build up the stability of the financial system. The apparent predictability under Basel II led to a dangerous feeling of security. It would therefore be more consistent and risk-averse to forego a risk weighting (Miller, 2016). As in Basel I, the rating should not be decisive for capital adequacy, but all loans should be subject to a flat rate of $8 \%$. Different creditworthiness could then be reflected, as in the periods of Basel I, in the banks' internal risk assessments, and thus in the loan interest rates. A global deterioration of the creditworthiness or an increase in the risks would not, as in the financial crisis, force a higher capital requirement in the short term, which would intensify the crisis. Then, government bonds should also be subject to equity, which seems urgent in view of the current international debt crisis.

\section{Introduction of a Separation System}

Debt write-offs for banks came mainly from investment banking, both in the financial crises and in the latest state debt crisis. There were also huge bonuses, which were paid out after short-term targets were reached. There should not be long-term credit risks here, which is why this bank is not subject to the credit rules. Bank-internal risk control and monitoring is much lower than in the credit sector. If, therefore, business with credit derivatives and bonds is to be continued in proprietary trading, the credit and default risks from investment banking should be subject to the same internal and external supervision and control. In particular, the rules on equity capital and the treatment of cluster risks must also apply to trading positions. Basel III stipulates that, the banks carry out their own model-based internal risk assessment in the purchase of bonds (securitization positions) and base the price risk in the account books on the basis of the investment portfolio with more equity. However, equity underwriting in the account books is still lower than in the 
investment portfolios, despite the fact that in the classic corporate and real estate lending businesses there were relatively minor failures in the financial crisis. In addition, the short-term trading positions, unlike corporate loans, are not included in the liquidity indices, which means they do not have to be refinanced. This is difficult to understand in light of the experience gained during the financial crisis when the markets for many trading positions disappeared. After the bankruptcy of Lehman many derivatives could no longer be sold. The failure of Lehman as a major derivative counterparty triggered the system crash. Lehman was too big to fail (Deutsche Bundesbank 2011; Götzl, 2012).

After the financial crisis fewer and bigger thus even more systemic relevant banks were left in de market (Miller, 2016). The designation of "too big to fail" was introduced in 1998 with the rescue of LTCM by the US Federal Reserve president Greenspan and has been considered irrefutable since then. Here, too, there is a breach of the market-based principle of private liability. This led to negative incentives, so-called moral hazard problems (Conrad \& Stahl, 2002; Conrad \& Stahl, 2003). The profits from high risk investments in the financial markets are only limited by a corresponding loss potential. For this, there is only one solution approach: system-relevant banks must be dismantled. Banks must also be able to go bankrupt in order for market incentives to work. Otherwise, a system change takes place moving toward a central administration economy, that is, to socialism. A break-up of the large corporations would also strengthen competition between the banks again.

An alternative approach would be the reintroduction of the separate banking system, i.e. the separation of investment and lending business. This would take account of the different business concepts of investment banking and commercial banking, and would give the financial institutions a non-contradictory objective function. An important argument for a separate bank system is greater risk transparency because processes and risks are handled through markets and are not visible only internally in a universal bank. The supporters of the universal system are opposed to the advantages of combining, scaling and information. However, the extremely high systemic costs of the financial crisis, which had to be borne mainly by taxpayers, are opposed to this (Blum, 2012).

The Glass Steagall Act and thus the separation system was abolished in 1999 by US President Clinton and his Finance Minister Rubin. It was originally introduced as a result of the financial crisis in 1929, which was mainly caused by a credit-financed stock bubble. Against the background of the experience in the financial crisis, the reintroduction in the USA or the international introduction of the separation banking system would only be consistent to prevent the transfer of risks from investment banking to credit banks and thus a systemic domino effect of outstanding claims and the transfer to the real economy. Investment banks would no longer be too big to fail and would no longer have to be saved by the state. According to the English Vickers report, the risky investment businesses are no longer allowed for retail banks internally shielded and demarcated within the framework of a ring-fence approach. By 2019, Britain's banks must have ringfenced their retail banking operations from their parent companies (Sachverständigenrat, 2011; Jenkins, 2017). Like the corresponding American Volcker rule in the Dodd Frank Act, these approaches are not as broad as the Glass Steagall Act (Conrad, 2013; Krahnen, Noth \& Schüwer, 2017).

The introduction of a separation system would only prevent the risks of investment banking from bleeding into to the retail area of banks, while the debtor and counterparty risk of the investment banking and the accompanying systemic risk would continue. A ban on retail banks financing hedge funds by offering credit - as the Vickers report demands - is a complementary conditio sine qua non. A possible total write-off must be considered when banks invest in investment houses, which is why we need a ban on the participation of retail banks in financial institutions with investment risks or at least giving up the value of these holdings. In the Dodd Frank Act the upper limit for investments in investment institutions was set at 3\%. These American and English approaches are structurally complementary to Basel III and should therefore be adopted by European governments. The Volcker rule served as a model for the German Separation Act, which came into force on 14 January 2014 (Kern, 2010; Sachverständigenrat, 2011; Conrad, 2013).

If the pure investment banks only had receivables and liabilities in a separate banking system, all the institutions could theoretically fail without the deposits and loans of the commercial bank system being affected. However, it is precisely the CDS that creates a risk division between all market players, which also entails a risk transfer from the investment banks to the commercial banks. In order to ensure the functioning of a separation system, it would therefore be important to exclude trade of CDSs between these two types of institutes.

\section{The Trade-off between Yield and Risk and Unilaterally Constructed Incentive Schemes}

The high credit risks associated with too little reserve equity also explain the relatively high returns in the financial sector. Between 2002 and 2003, the profits of the financial sector accounted for $40 \%$ of domestic corporate profits, and between 2009 and 2011 still 25\% (Dullien, 2012). The credit risk of the CDS was not covered by equity as it is with comparable loans, which is why the banks have shown much higher profits in recent years than would have been permissible. When then the bad years came in the form of the subprime crisis, no capital was available to bear the losses. Many speculators had to be bailed out because their failure threatened the financial system. On the other hand, the bonuses were paid in the good years and did not have to be repaid as it turned out that the reported earnings were not 
sustainable. The financial crisis thus also revealed weaknesses in corporate governance. The bonuses of the companies violated the principle of liability, because only the short-term goal was rewarded. Long-term negative developments were not considered.

An experiment showed that unilaterally constructed incentive schemes encourage excess risk-taking. This would indicate that common bonus-based compensation schemes are not a good idea and in fact enhance risk because of the asymmetries in the treatment of gains and losses (Conrad, 2015). In most cases compensation can only decrease down to the base salary while gains from bonuses can be limitless. Short-term results are rewarded even when these results are subsequently reversed. This encourages risk-taking by the employees (agents) at the cost of the company (the principal). They undertake actions that generate a high probability of gains in the short-term while the risk of a larger loss in the longer-term is not taken into consideration, thus becoming a liability to the principal. This does not align with the basic idea of principal-agent theory. Of course a connection between a manager's compensation and a firm or manager`s performance will promote better incentive alignment and lead to higher motivation, which increases firm value, but only if losses and profits are remunerated symmetrically.

The existing asymmetries of bonus compensation schemes have led to a divergence of interests between employees on the one hand and the health of financial institutions and other companies at large on the other hand. Compensation packages for CEOs and other managers have gotten out of control. Remuneration and bonuses depend on short-term profitability, which increases share prices in the short-term, but not the long-term health of the company. In the financial system, investment managers increased the risks for their employer by buying highly profitable but risky assets and were rewarded with high bonuses, which led to the financial crisis in the long term. In addition, the review of research literature showed that cheating is promoted by high and unilateral variable compensations. CEOs have incentives to manipulate earnings if executive compensation is strongly linked to performance. Opportunistic earnings management behavior has been detected.

Risk adequate compensation is therefore an important prerequisite for good performance in all risk-handling professions. Without accountability, variable compensation schemes become unilateral bonus maximation schemes with negative effects for the company and the principal. It means risking other people's money which will generally be abused (moral hazards) (Andersson, O., Holm, H. J., Tyran, J. \& Wengström, E., 2013).

In view of the principal agent problem and the resulting lack of shareholder control, a state intervention seems unavoidable to prevent moral hazard. The Dodd Frank Act offers at least a legal basis to demand that overly generous bonuses be repaid, in the event of a balance sheet correction (Kern, 2010). In addition, many bank managers seem to lack the professional qualification to correctly assess the risks from subprime loans. This also reveals weaknesses in corporate governance, particularly in the case of staff recruitments. Here, the national financial supervisory authorities are called upon to review in particular the experience of the board members in the lending business.

\section{Fair Value Loan Valuation}

Bank loans are not impaired until they are no longer serviced or permanent deteriorations in the creditworthiness of the borrower exist, which jeopardize the repayment of the loan. One problem, however, is the balance sheet valuation of tradable loans, so-called securitizations, at fair value, i.e. at market value. This was reflected in the financial crisis when the markets for the CDOs had fallen away and the values plummeted. In other words, the fair values were meaningless because of exaggerated values, and they devolved into understated values because of lack of demand and transparency.

The fair value problem reappeared again during the European debt crisis. As the prices of government bonds declined, many European banks needed fresh equity because the price losses resulted in write-offs. US-GAAP and IFRS are aligned to the shareholder's informational needs, which reflect the level of the fair value. A long-term evaluation based on creditor protection and caution would be more appropriate, as it avoids excessive volatility in both revaluations and devaluations (Ballwieser, Küting \& Schildbach, 2009). Market values are determined by supply and demand. This can lead to imbalances that have nothing to do with creditworthiness, or to exaggeration and understatement through herding, that is, irrational human mass behavior (Conrad, 2005). Here, there should be a balance sheet option to suspend the market value on the basis of current internal ratings that can be verified by the bank supervisor, for trading positions such as loans. The IFRSs are to be geared more strongly to long-term values (Ballwieser, Küting \& Schildbach, 2009).

\section{Conclusion and Reform Proposals}

Many scientists see a distorting market interaction in the restriction of speculation. They see themselves as advocates of liberalized markets, or market-based basic functions. However, the so-called liberalization of the markets around the year 2000 allowed derivatives instruments, which were not market-compliant because they relate to goods or values but do not have to correspond to any real demand or supply. In addition, non-commercial actors were admitted to the market with non-economic but speculative objectives. This has dramatically increased systemic risk.

The biggest shortcoming of the recent reforms to the stabilization of the financial system, such as Basel III and the 
American Dodd Frank Act, is that they increase the capital requirements rather than the causes of the increased risk. They do this in order to absorb the increased risk of speculation following the financial market deregulation and the spreading of derivatives, yet this also greatly increases the costs of borrowed capital. This means that growth losses are accepted and the costs of the financial crisis are once again forced upon the general public.

An alternative option to limit systemic risk would be the internalization of systemic risk into market prices. High capital requirements could be renounced if the systemic risks arising from non-regulated financial contractors are correctly priced or reported. It would be feasible to levy a risk tax on transactions with offshore institutions and other counterparties from unregulated financial markets that create a systemic risk but are not subject to the new regulatory requirements. This could be in the form of a flat-rate penalty tax or on the basis of an analysis of the respective systemic risk. In addition, a valuation discount for the claims against these institutions would be required under accounting law.

This would also reduce the problem of the prisoner's dilemma. The cost of the risk posed by these institutions would be internalized and free-rider benefits reduced. This tax could be collected individually by each state, thus without international financial market regulation. This would be in line with the Basel III regulation described above, which provides additional capital requirements for the risk of default for derivatives that are not settled via central counterparties. However, the problem of market influence by speculation with derivatives remains.

It would generally be better to forbid risky and complex financial products than to further increase regulation complexity and the capital requirements as in Basel III and the American Dodd Frank Act. Real-world problems can arise from the investor behavior whenever there are raw materials that fulfill important economic functions, such as foodstuffs. In the case of commodity trading, the position limits should therefore be reintroduced and the leverage of the derivatives restricted. As with medicines, derivatives should be reviewed by their national regulatory authorities for their systemic risk and transparency before they enter the market. Consumer protection should also be considered. No non-transparent derivatives with unlimited risk such as credit-ladder swaps should be permitted.

Only as insurance do derivatives have economic advantages. Derivatives should therefore be permitted only to hedge risks, just before deregulation as a financial instrument, i.e. only in connection with a basic transaction. A corresponding regulation would be an important contribution to the reduction of market influence and systemic risk caused by derivatives. For example, a physical settlement could be prescribed for all derivatives, such as the transfer of the reference security or the corresponding goods. This speculative instrument would be omitted for hedge funds. Speculation would then have to be carried out as before with equity or borrowed capital, thus without the leverage effect of derivatives, which would significantly reduce systemic risk.

\section{Reference}

Andersson, O., Holm, H. J., Tyran, J., \& Wengström, E. (2013). Risking Other People’s Money: Experimental Evidence on Bonus Schemes, Competition, and Altruism. IFN Working Paper No. 989. www.ifn.se/wfiles/wp/wp989.pdf.

Ballwieser, W., Küting, K., \& Schildbach, T. (2009). Fair Value in der Krise. Der Betrieb, 04/12/2009, 49.

Blum, U. (2012). Pro Trennbankensystem: Transparente Systematik, Wirtschaftsdienst, 92(1).

Conrad, C. A. (2005). Kapitalallokation in der Irrational Exuberance - Erkenntnisse aus Theorie und Praxis, In R. Eller et al. (Eds.), Handbuch Asset Management, 387-406. Stuttgart: Schäffer-Poeschel.

Conrad, C. A. (2010). Morality and Economic Crisis - Enron, Subprime \& Co., Hamburg: disserta.

Conrad, C. A. (2013). Auf dem Weg zu einer besseren Finanzmarktordnung. Bankarchiv (Journal of Banking and Finance), 61, 233-241.

Conrad, C. A. (2014). Commodity and Food Speculation, Is There a Need for Regulation? A Discussion of the International Research. Applied Economics and Finance, 1(2), 58-64. https://doi.org/10.11114/aef.v1i2.548

Conrad, C. A. (2015). Incentives, Risk and Compensation Schemes: Experimental Evidence on the Importance of Risk Adequate Compensation. Applied Economics and Finance, 2(2), 50-55. https://doi.org/10.11114/aef.v2i4.1053

Conrad, C. A., \& Stahl, M. (2002). Parallels with the 1920s stock market boom and the monetary policy. Kredit und Kapital, 35(4), 533-549.

Conrad, C. A., \& Stahl, M. (2003). Geldpolitik und Spekulationsblasen - Das Beispiel der USA. Österreichisches Bankarchiv, Zeitschrift für das gesamte Bank- und Börsenwesen, 51, 685-693.

Crotty, J. (2009). Structural causes of the global financial crisis: a critical assessment of the 'new financial architecture'. Cambridge Journal of Economics, 33(2009), 563-580. https://doi.org/10.1093/cje/bep023

Deutsche Bundesbank. (2011). Leitfaden zu den neuen Eigenkapital- und Liquiditätsregeln für Banken, Frankfurt. https://www.bundesbank.de/Redaktion/DE/Downloads/Veroeffentlichungen/Bundesbank/basel3_leitfaden.pdf?_b 
lob=publicationFile

Domanski, D., \& Heath, A. (2007). Financial investors and commodity markets. BIS Quarterly Review, March(2007), 53-67, https://www.bis.org/publ/qtrpdf/r_qt0703g.pdf (12.02.2014).

Dullien, S. (2012). Bankenregulierung: Schwindende Statik. Wirtschaftsdienst, 92(7), 431-434. https://doi.org/10.1007/s10273-012-1402-3

European Commission. (2011). Proposal for a Regulation of the European Parliament and oft the Council on Prudential Requirements for Credit Institutions and Investment Firms, COM (2011) 452.

Fox, J. (2009). The Myth of the Rational Market, A History of Risk, Reward, and Delusion on Wall Street, New York: HarperBusiness.

Gaumert, U., Götz, S., \& Ortgies, J. (2011). Basel III - eine kritische Würdigung, die bank - Zeitschrift für Bankpolitik und Praxis, 2011(5). http://www.die-bank.de/betriebswirtschaft/basel-iii-2013-eine-kritische-wurdigung

Giancarlo, H. J. C. (2016). Reconsidering the Dodd- Frank Swaps Trading Regulatory Framework. In H. Peirce \& B. Klutsey (Eds.), Reframing Financial Regulation - Enhancing Stability and Protecting Consumers, Mercatus Center, George Mason University, Arlington Virginia, (pp. 155-179).

Götzl, S. (2012). Fokussiert: Baseler Paradoxien, http://www.gv-bayern.de/Admin/GVB_Module/Druckversion/Druckversion?artikel=73627.

Hayek, F. A. V. (1974). The Pretence of Knowledge, Lecture to the memory of Alfred Nobel, December 11, 1974. https://www.nobelprize.org/nobel_prizes/economic-sciences/laureates/1974/hayek-lecture.html

Hofmann, $\quad$ C. $\quad$ (2011). $\quad$ Basel $\quad$ III $\quad-\quad$ Kontrahentenrisiko. http://www.1plusi.de/dokumente/1_plus_i_fachbeitrag_basel_3_Kontrahenten.pdf (Abfrage vom 27.12.2011).

Jenkins, P. (2017, December 18). Why UK bank ringfences don't make everyone safer. Financial Times. https://www.ft.com/content/1d529c3c-e1a6-11e7-a8a4-0a1e63a52f9c

Kern, S. (2010). US-Finanzmarktreform, Deutsche Bank Research, Finanzmarkt Spezial, EU-Monitor, 77, http://www.db.com/mittelstand/downloads/US_Finanzmarktreform_12_2010.pdf

Kling, A. (2016). Risk- Based Capital Rules. In H In H. Peirce \& B. Klutsey (Eds.), Reframing Financial RegulationEnhancing Stability and Protecting Consumers, Mercatus Center, George Mason University, Arlington Virginia, 13-34.

Krahnen, J. N., \& Schüwer, U. (2017). Structural Reforms in Banking: The Role of Trading. Journal of Financial Regulation, 3(1), 66-88. https://doi.org/10.1093/jfr/fjw018

Krugman, P. (2008, June 21). Calvo on commodities, New York Times, http://krugman.blogs.nytimes.com/2008/06/21/calvo-on-commodities/?_php=true\&_type=blogs\&_r=0.

Lagi, M., Bar, Y. Y., Bertrand, K. Z., \& Bar, Y. Y. (2011). The Food Crises, A Quantitative Model of Food Prices Including Speculators and Ethanol Conversion, New England Complex Systems Institute. Cambridge. http://necsi.edu/research/social/food_prices.pdf

Malkiel, B. (2014). What Does The Efficient Market Hypothesis Have To Say About Asset Bubbles? https://www.forbes.com/sites/quora/2014/06/13/what-does-the-efficient-market-hypothesis-have-to-say-about-asset -bubbles/amp/

Miller, S. M. (2016). On Simpler, Higher Capital Requirements. In H. Peirce \& B. Klutsey (Eds.), Reframing Financial Regulation - Enhancing Stability and Protecting Consumers, Mercatus Center, George Mason University, Arlington Virginia, 35-59.

Peirce, H., \& Soliman, V. (2016), Rethinking the Swaps Clearing Mandate. In H. Peirce \& B. Klutsey (Eds.), Reframing Financial Regulation - Enhancing Stability and Protecting Consumers, Mercatus Center, George Mason University, Arlington Virginia, 180-224.

Pies, I., Prehn, S., Glauben, T., \& Will, M. G. (2013). Kurzdarstellung Agrarspekulation, Diskussionspapier, 2013-2, Halle: $\quad$ Martin-Luther-Universität http://wcms.uzi.uni-halle.de/download.php?down=27545\&elem=2636563

Sachverständigenrat. (2011). Verantwortung für Europa wahrnehmen, Wiesbaden 2011. https://www.sachverstaendigenrat-wirtschaft.de/fileadmin/dateiablage/download/gutachten/ga11_ges.pdf

Schäfer, D. (2011). Banken: Leverage Ratio ist das bessere Risikomaß. DIW Wochenbericht, 46. http://www.diw.de/documents/publikationen/73/diw_01.c.388897.de/11-46-3.pdf 
Single, G., \& Stahl, M. (2000), Risikopotential Hedge-Fonds - der Fall LTCM. In C. A. Conrad, \& Stahl, M. (Eds.), Risikomanagement an den internationalen Finanzmärkten, 379-391. Stuttgart: Schäffer-Poeschel.

Soros, G. (2009, March 24). One Way to Stop Bear Raids. Credit default swaps need much stricter regulation. The Wall Street Journal. https://www.wsj.com/articles/SB123785310594719693

Stahl, M., \& Conrad, C. A. (2000). Strategien zur Risikovermeidung an internationalen Finanzmärkten. In C. A. Conrad, \& Stahl, M. (Eds.), Risikomanagement an den internationalen Finanzmärkten, 207-221. Stuttgart: Schäffer-Poeschel.

Stoll, H. R., \& Whaley, R. E. (2009). Commodity index investing and commodity future prices, Owen Graduate School of $\quad$ Management, 2009. http://www.cftc.gov/ucm/groups/public/@swaps/documents/file/plstudy_45_hsrw.pdf

Stulz, R. (2009, March 2009). Six Ways Companies Mismanage Risk, Harvard Business Review, 86-94.

Stulz, R. M. (2010). Credit Default Swaps and the Credit Crisis. Journal of Economic Perspectives, 24(1), 73-92. https://doi.org/10.1257/jep.24.1.73

Taleb, N. N. (2001). Fooled by Randomness, Penguin.

Taleb, N. N. (2007). The Black Swan; The Impact of the Highly Improbable, Penguin.

US-Senate, Brief Summary of The Dodd-Frank Wall Street Reform And Consumer Protection Act. http://banking.senate.gov/public/_files/070110_Dodd_Frank_Wall_Street_Reform_comprehensive_summary_Fina 1.pdf. https://www.dpc.senate.gov/pdf/wall_street_reform_summary.pdf

Voinea, G., \& Anton, S. (2009), Lessons from the Current Financial Crisis. A Risk Management Approach. Review of Economic and Business Studies, 3, 139-147.

\section{Copyrights}

Copyright for this article is retained by the author(s), with first publication rights granted to the journal.

This is an open-access article distributed under the terms and conditions of the Creative Commons Attribution license which permits unrestricted use, distribution, and reproduction in any medium, provided the original work is properly cited. 